\title{
RSK activation via ERK modulates human colon cancer cells response to PTHrP
}

\author{
Natalia Calvo, Pedro Carriere, María Julia Martin and Claudia Gentili \\ Departamento de Biología, Bioquímica y Farmacia, INBIOSUR, Universidad Nacional del Sur \\ (UNS) - CONICET, Bahía Blanca, Argentina
}

Correspondence should be addressed to C Gentili

Email

cgentili@criba.edu.ar

\begin{abstract}
Parathyroid hormone-related peptide (PTHrP) is associated with several human cancers such as colon carcinoma. This disease is a complex multistep process that involves enhanced cell cycle progression and migration. Recently we obtained evidence that in the human colorectal adenocarcinoma Caco2 cells, exogenous PTHrP increases the proliferation and positively modulates cell cycle progression via ERK1/2, p38 MAPK and $\mathrm{PI3K}$. The purpose of this study was to explore if the serine/threonine kinase RSK, which is involved in the progress of many cancers and it is emerging as a potential therapeutic target, mediates PTHrP effects on cancer colon cells. Western blot analysis revealed that PTHrP increases RSK phosphorylation via ERK1/2 signaling pathway but not through p38 MAPK. By performing subcellular fractionation, we found that the peptide also induces the nuclear localization of activated RSK, where many of its substrates are located. RSK participates in cell proliferation, in the upregulation of cyclin D1 and CDK6 and in the downregulation of p53 induced by PTHrP. Wound healing and transwell filter assays revealed that cell migration increased after PTHrP treatment. In addition, the hormone increases the protein expression of the focal adhesion kinase FAK, a regulator of cell motility. We observed that PTHrP induces cell migration and modulates FAK protein expression through ERK/RSK signaling pathway but not via p38 MAPK pathway. Finally, in vivo studies revealed that the hormone activates RSK in xenografts tumor. Taken together, our findings provide new insights into the deregulated cell cycle and migration that is characteristic of tumor intestinal cells.
\end{abstract}

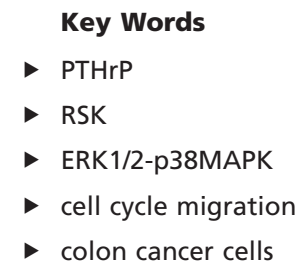

Journal of Molecular Endocrinology (2017) 59, 13-27

\section{Introduction}

The parathyroid hormone-related protein (PTHrP), originally identified as the factor responsible for malignant hypercalcemia, was later found to be widely expressed in fetal and adult tissues. Today it is recognized for its endocrine, paracrine and autocrine modes of action (Maioli \& Fortino 2004, McCauley \& Martin 2012). Fulllength PTHrP undergoes posttranslational processing, which gives rise to a family of mature secretory peptides
(Wysolmerski 2012). Peptides with the N-terminal PTHlike region, such as PTHrP (1-34), bind to and activate the PTH/PTHrP receptor (PTH1R), whereas midregion and C-terminal peptides are functionally active through uncharacterized receptors (Wysolmerski 2012). Cytosolic PTHrPcanalsouseabipartite multibasicnuclearlocalization signal to translocate to the nucleus and act through an intracrine pathway (McCauley \& Martin 2012). There is

Published by Bioscientifica Ltd 
evidence that the hormone is implicated in different cancers such as colon carcinoma (McCauley \& Martin 2012), one of the major causes of cancer death worldwide (Curtin 2013, Siegel et al. 2015). Although great progress has been made in the diagnosis and therapy of the colon cancer, the survival rate is still low (Chan et al. 2012). Therefore, investigation of the underlying mechanisms for the tumorigenesis of colon cancer will facilitate the diagnosis and therapy of the colon cancer. The pathogenesis of this disease involves various processes including enhanced cell survival, cell cycle progression, proliferation, migration and angiogenesis. PTHrP can participate in these processes, promoting tumor growth and dissemination by the regulation of different signaling pathways (Sourbier \& Massfelder 2006).

The p90 ribosomal S6 kinase (RSK) comprises a family of serine/threonine kinases that are activated by MAPK family. Four isoforms, RSK1-4, have been reported in mammalian cells (Anjum \& Blenis 2008, Lara et al. 2013). The best functionally characterized isoforms are RSK1 and RSK2. Each RSK isoform contains two nonidentical kinase domains, one at the N-terminus and one at the C-terminus. Phosphorylation of RSKs at serine/threonine residues, which occurs at multiple sites, is required for its activation (Anjum \& Blenis 2008) and the N-terminal kinase domain is primarily responsible for substrate phosphorylation. RSKs phosphorylate many proteins, both cytosolic and nuclear (Romeo et al. 2012). The many effects of these kinases on various proteins may contribute to the observations that RSKs mediate wide-ranging cellular processes, including cell cycle and migration (Lara et al. 2013, Wu et al. 2014, Zhou et al. 2015).

RSK signaling is involved in many cancers, controls oncogenic processes through the regulation of transcription factors and/or cellular modulators (Romeo et al. 2012, Lara et al. 2013, Sulzmaier \& Ramos 2013). Theses kinases also regulate protein synthesis, and therefore, RSK-mediated translational control may play a critical role in the regulation of tumorigenic cellular events.

As RSK has been shown to contribute to the etiology of numerous cancers, new therapeutic strategies could be included in anti-cancer chemotherapy (Hecht et al. 2015, Poomakkoth et al. 2016). Thus, RSKs emerge as potential therapeutic targets in various types of human cancer (Romeo et al. 2012, Lara et al. 2013, Sulzmaier \& Ramos 2013).

In SNU-407 colon cancer cells, carbachol treatment induced RSK activation in an atropine-sensitive manner, and this RSK activation was decreased by the inhibition of either the epidermal growth factor receptor (EGFR) or protein kinase C (PKC). Moreover, the inhibition of RSK almost completely blocked carbachol-stimulated cell proliferation (Park \& Cho 2012). However, the molecular mechanisms leading to RSK activation as well as its role in colon cancer cells is not fully studied.

Recently, we obtained evidence that in Caco2 cells and HCT116 cells, two cell lines from human intestine tumors, exogenous PTHrP activates ERK1/2 as well as the $\alpha$ isoform of p38 MAPK. The hormone also increases cell proliferation, modulates cell cycle progression and exerts a protective effect under apoptotic conditions via MAPK signaling pathways in these tumor intestinal cells (Lezcano et al. 2013, Calvo et al. 2014, Martin et al. 2014; Martín MJ, Gigola G, Carriquiriborde M, Gentili F \& Gentili C, unpublished observations).

Based on our observations and given the relevance of signaling pathways associated with cell cycle and cell migration in the spread of cancer and the complex inputs capable of modulating these processes, the aim of the present study was to investigate whether in Caco2 cells and HCT116 cells, PTHrP activates RSK and if so, to explore whether this kinase mediates the effects of PTHrP on colon cancer cells and the molecular mechanisms that are involved in these processes. To validate the results observed from in vitro studies, we also evaluated the hormone effect in vivo.

\section{Materials and methods}

\section{Materials}

Human PTHrP (1-34) and high glucose Dulbecco's modified Eagle's medium (DMEM) were obtained from Sigma-Aldrich Chemical. Fetal bovine serum (FBS) was from Natocord (Córdoba, Argentina). Antibodies were from the following sources: anti-RSK1/2/3, anti-FAK, anti-cyclin D1, anti-CDK-6 and anti-p53 were from Cell Signaling Technology. Anti-phospho RSK, antiGAPDH, anti-phospho tyrosine antibody, goat anti-rabbit peroxidase-conjugated secondary antibody and goat antimouse peroxidase-conjugated secondary antibody were from Santa Cruz Biotechnology. PD 98059 and SB 203580 were from Calbiochem. SL0101 was from Santa Cruz Biotechnology. SB 202190 was from Tocris Bioscience (United Kingdom). Crystal violet was from MERCK. Protein size markers were from Amersham Biosciences, PVDF (Immobilon polyvinylidene difluoride) membranes and ECL chemiluminescence detection kit were from Amersham. Transwell filters were with the following features: polyethylene terephthalate (PET), $8 \mu \mathrm{m}$ pores,

Published by Bioscientifica Ltd. 
24-well format, were from JETBIOFIL. All other reagents used were of analytical grade.

\section{Cell culture and treatment}

The human colon cell lines Caco2 and HCT 116 (from the American Type Culture Collection, Manassas, VA, USA) were cultured at $37^{\circ} \mathrm{C}$ in DMEM containing $10 \%$ FBS, $1 \%$ non-essential acids, $100 \mathrm{IU} / \mathrm{mL}$ penicillin, $100 \mathrm{mg} /$ $\mathrm{mL}$ streptomycin and $50 \mathrm{mg} / \mathrm{mL}$ gentamycin in a humid atmosphere of $5 \% \mathrm{CO}_{2}$ in air. Cultures were passaged every 2 days with fresh medium. All experiments were performed using passages less than 15. Experimental cultures were grown to $80 \%$ confluence in serumcontaining medium, and then cells were serum-deprived $24 \mathrm{~h}$ before the addition of $10^{-8} \mathrm{~mol} / \mathrm{L}$ PTHrP (1-34) for different times. This dose of exposure was selected because we previously studied the effects of PTHrP (1-34) $10^{-8} \mathrm{~mol} / \mathrm{L}$ in Caco2 cells and HCT 116 cells expressing PTH/PTHrP receptor (Lezcano et al. 2013, Calvo et al. 2014, Martín et al. 2014). Where indicated, cells were pretreated for $30 \mathrm{~min}$ with SL0101 (an inhibitor of RSK), PD 98059 (an inhibitor of MEK, which is the upstream kinase of ERK1/2), SB 203580 (an inhibitor of p38 MAPK) or SB 202190 (another inhibitor of p38 MAPK). Control conditions were performed by addition of an equivalent volume of DMSO (the vehicle of the inhibitors). In previous works, we confirmed the effectiveness of the kinases inhibitors employed, SB 203580 and PD 98059, by determining phosphorylated protein levels of CREB/ ATF1 or ERK, respectively, by Western blot analysis (Lezcano et al. 2013, Calvo et al. 2014, Martín et al. 2014). The kaempferol glycoside SL0101 is an ATP-competitive inhibitor of the kinase domain N-terminal (NTKD) and was in fact the first identified specific inhibitor of RSK. SL0101 is a natural product obtained from the tropical plant Forsteronia refracta. The $\mathrm{EC}_{50}$ of SL0101 was found to be approximately $50 \mu \mathrm{mol} / \mathrm{L}$ in intact cells (Smith et al. 2005).

\section{Trypan blue dye exclusion assay}

Caco 2 cells were seeded at a density of $2 \times 10^{4}$ cells/well in 24-well plate. Cells were pre-incubated with or without RSK inhibitor SL0101 $(50 \mu \mathrm{mol} / \mathrm{L})$ for $30 \mathrm{~min}$ and then treated with PTHrP in triplicates for 5 days. Then, the cells were washed with PBS buffer, released from the cultured dish using trypsin-EDTA, incubated with $0.4 \%$ of Trypan blue stain and counted in a Neubauer chamber observed in a microscope. Cells were counted per field, and the number of cells that excluded the stain (viable cells) was determined in each condition.

\section{Wound healing assay}

Cells were seeded in a 6-well plate and grown to confluency. The cell monolayer was wounded by scratching, using a $10 \mu \mathrm{L}$ pipette tip. After washing with a phosphate-buffered saline solution (PBS), the cells were incubated with or without PTHrP $\left(10^{-8} \mathrm{~mol} / \mathrm{L}\right)$. At time points $0,4,24$ and $48 \mathrm{~h}$, the same positions along the scratch wound were photographed using a microscope (NIKON Eclipse Ti-S) and ImageJ (MRI Wound Healing Tool) was used for quantification of the scratch wound. Three measurements per scratch were performed ( 2 replicates/condition, $n=3$ experiments).

\section{Transwell migration assay}

Cells were seeded on the top of transwell filters and were grown for $48 \mathrm{~h}$ followed by serum starvation for another $24 \mathrm{~h}$ in medium without FBS. Then, the medium in the lower chamber was replaced by medium containing 5\% FBS while the medium in filter inserts was replaced by serum-free medium with or without PTHrP $\left(10^{-8} \mathrm{~mol} / \mathrm{L}\right)$. Cells were incubated with the hormone for $18 \mathrm{~h}$ in HCT 116 cells or for $24 \mathrm{~h}$ in $\mathrm{Caco} 2$ cells and the treatment was finalized when they were washed twice with PBS followed by fixation using methanol for $15 \mathrm{~min}$ at $-20^{\circ} \mathrm{C}$. Then, the cells on the upper side of the transwell filters were removed with a cotton swab while the cells on the lower side were stained with $0.1 \%$ crystal violet for $30 \mathrm{~min}$ at room temperature. Where indicated, cells were pretreated for 30 min with RSK or MAPKs inhibitors. Migrated cells were counted using an inverted microscope (2 replicates/ condition, $n=3$ experiments).

\section{Western blot analysis}

Cells were washed with PBS buffer plus $25 \mathrm{mmol} / \mathrm{L} \mathrm{NaF}$ and $1 \mathrm{mmol} / \mathrm{L} \mathrm{Na} \mathrm{VO}_{4}$, and lysed in buffer containing $50 \mathrm{mmol} / \mathrm{L}$ Tris- $\mathrm{HCl}$ (pH 7.4), $150 \mathrm{mmol} / \mathrm{L} \mathrm{NaCl}, 3 \mathrm{mmol} / \mathrm{L}$ $\mathrm{KCl}, 1 \mathrm{mmol} / \mathrm{L}$ EDTA, $1 \%$ Tween-20, $1 \%$ Nonidet P-40, $20 \mu \mathrm{g} / \mathrm{mL}$ aprotinin, $20 \mu \mathrm{g} / \mathrm{mL}$ leupeptin, $1 \mathrm{mmol} / \mathrm{L}$ phenylmethylsulfonyl fluoride (PMSF), $25 \mathrm{mmol} / \mathrm{L} \mathrm{NaF}$ and $1 \mathrm{mmol} / \mathrm{L} \mathrm{Na}_{3} \mathrm{VO}_{4}$. The lysates were incubated on ice for $10 \mathrm{~min}$, vortexed for $45 \mathrm{~s}$ and maintained on ice for another $10 \mathrm{~min}$. After centrifugation at $14,000 \mathrm{~g}$ and $4^{\circ} \mathrm{C}$ for $15 \mathrm{~min}$, the supernatant was collected and proteins were quantified by the Bradford method (Bradford 1976).

Published by Bioscientifica Ltd. 
Lysate proteins dissolved in $6 \times$ Laemmli sample buffer were separated $(30 \mu \mathrm{g} / \mathrm{lane})$ using SDS-polyacrylamide gels (8-12\% acrylamide) and electrotransferred to PVDF membranes. After blocking with 5\% nonfat milk in TBST buffer ( $50 \mathrm{mmol} / \mathrm{L}$ Tris pH 7.2-7.4, $200 \mathrm{mmol} / \mathrm{L} \mathrm{NaCl}, 0.1 \%$ Tween-20), the membranes were incubated overnight with the appropriate dilution of primary antibody in TBST with $1 \%$ nonfat milk. After washing, membranes were incubated with the appropriate dilution of horse radish peroxidase-conjugated secondary antibody in TBST with $1 \%$ nonfatmilk. Finally, the blots were developed by ECL with the use of Kodak BioMax Light film and digitalized with a GS-700 Imaging Densitomer (Bio-Rad).

\section{Stripping and reprobing membranes}

The complete removal of primary and secondary antibodies from the membranes was achieved by incubating the membranes in stripping buffer $(62.5 \mathrm{mmol} / \mathrm{L}$ Tris- $\mathrm{HCl}$, $\mathrm{pH} 6.8,2 \%$ SDS and $50 \mathrm{mmol} / \mathrm{L} \beta$-mercaptoethanol) at $55^{\circ} \mathrm{C}$ for $30 \mathrm{~min}$ with agitation. Then, membranes were washed for $10 \mathrm{~min}$ in TBST (1\% Tween-20) and blocked, as indicated previously, for $1 \mathrm{~h}$ at room temperature. After that, membranes were ready to reprobe with the corresponding antibodies.

\section{Subcellular fractionation}

Cells were washed with PBS, resuspended in ice-cold TES buffer $(50 \mathrm{mmol} / \mathrm{L}$ Tris-HCl (pH 7.4), $1 \mathrm{mmol} / \mathrm{L}$ EDTA, $250 \mathrm{mmol} / \mathrm{L}$ sucrose-containing inhibitors) homogenized in a Teflon-glass hand homogenizer (30 stokes) and then centrifuged at $80 \mathrm{~g}$ for $20 \mathrm{~min}$ at $4^{\circ} \mathrm{C}$. The supernatant was centrifuged at $1400 \mathrm{~g}$ for $20 \mathrm{~min}$ at $4^{\circ} \mathrm{C}$ to pellet the nuclei. The resulting supernatant was used as cytosolic fraction. The pellet was washed twice in TES buffer, resuspended in the lysis buffer described previously for Western blot and used as nuclear fraction. The purity of each isolated fraction was assessed by assaying for proteins known to be associated with cellular components. Proteins from each fraction were quantified by the Bradford method (Bradford 1976). Equal proteins from each fraction were dissolved in $6 \times$ Laemmli sample buffer and separated (30 $\mu \mathrm{g} / \mathrm{lane})$ using SDS-polyacrylamide gels ( $8 \%$ acrylamide).

\section{Xenograft in nude mice}

$1 \times 10^{6}$ human colorectal carcinoma (HCT116) cells were subcutaneously injected into the left dorsal flanks of 6-week-old BALB/c male nude mice. Four days after inoculation, animals were randomized (blindly) into control and treatment groups ( $n=6 /$ group). Mice were administered daily with PTHrP $(40 \mu \mathrm{g} / \mathrm{kg}$ in $200 \mu \mathrm{L}$ PBS $)$ or an equal volume of vehicle solution, as control, by intratumoral injection ( 2 groups in total; each group represents an experimental unit). The mice were killed and tumors were removed and weighted after the 20 days of PTHrP treatment. Tumor size was calculated according to the following formula: tumor volume $\left(\mathrm{mm}^{3}\right)=$ tumor width $\left(\mathrm{mm}^{2}\right) \times$ tumor length $(\mathrm{mm}) / 2$ (Wang et al. 2002). All experiments with animals were approved by a local animal committee for ethics. One piece of each tumor was fixed with $4 \%$ neutral buffered formaldehyde solution for immunohistochemistry assay.

\section{Immunohistochemistry}

Paraffin-embedded sections were deparaffinized, re-hydrated and pre-treated using heat-mediated antigen retrieval (using a pressure cooker) with sodium citrate buffer $(10 \mathrm{mM}, \mathrm{pH} 6)$ for $15 \mathrm{~min}$. After the antigen retrieval step, sections were washed and blocked in $30 \% \mathrm{H}_{2} \mathrm{O}_{2}$, and the primary antibody (anti-phospho RSK) was added for overnight incubations at $4^{\circ} \mathrm{C}$. Immunohistochemical staining was carried out manually using ABCAM Detection IHC Kit (ABCAM) according to the manufacturer's instructions. Finally, the slides were monitored under microscope and the reaction was stopped with distilled water, counterstained with hematoxylin, dehydrated and coverslipped. Staining was visualized using a light microscope.

\section{Statistical analysis}

The statistical significance of the data was evaluated using Student's $t$ test (Snedecor \& Cochran 1989), and probability values below $0.050(P<0.050)$ were considered significant. Quantitative data are expressed as means \pm S.D. from the indicated set of experiments.

\section{Results}

\section{PTHrP increases RSK phosphorylation via ERK1/2 in tumor intestinal cells}

RSK signaling is involved in many cancers, including colon cancer (Park \& Cho 2012). Phosphorylation of this kinase at serine/threonine residues, which occurs at multiple sites, is required for its activation (Anjum \& Blenis 2008).

Published by Bioscientifica Ltd. 
With the aim of elucidating whether exogenous PTHrP is able to activate RSK in the tumor intestinal cells, we investigated the changes in the phosphorylation state of this kinase in Caco 2 cells and HCT 116 cells. To that end, the cells were exposed for different times to PTHrP, whole cell lysates were subjected to SDS-PAGE and then immunoblotted using a phospho-specific antibody against the Ser-363 and Thr-359 residues of RSK. We observed that PTHrP markedly increased RSK phosphorylation in a time-dependent manner in both Caco2 cells and HCT 116 cells (Fig. 1, left panel and right panel, respectively). The maximal stimulation was achieved at $1 \mathrm{~h}$ and declined at $24 \mathrm{~h}$ of treatment with the peptide. The protein levels of total RSK1/2/3 were no different in the absence or presence of PTHrP demonstrating a true increase in their phosphorylation status.

We found that PTHrP activates ERK1/2 and p38 MAPK in Caco2 cells (Martín et al. 2014) and in HCT 116 cells (Martin et al. unbulished work). RSK can be phosphorylated by ERK1/2 on threonine 573, threonine 359 and serine 363 residues (Lara et al. 2013) and by p38 MAPK indirectly on tyrosine 529 residue (Czaplinska et al. 2014). In order to investigate the involvement of MAP kinases in PTHrP-dependent RSK phosphorylation, tumor intestinal cells were pre-incubated in the presence or absence of MAPKs inhibitors for $30 \mathrm{~min}$ and then treated for $1 \mathrm{~h}$ with or without the hormone. As shown in Fig. 2A, PD $98059(20 \mu \mathrm{mol} / \mathrm{L})$, a specific inhibitor of MEK1/2 (the upstream kinases of ERK1/2), totally blocked the phosphorylation of RSK induced by PTHrP while SB $203580(20 \mu \mathrm{mol} / \mathrm{L})$, an $\alpha$ and $\beta$ p38 MAPK inhibitor, did not reverse PTHrP effect in both, Caco2 cells and HCT 116 cells (left panel and right panel, respectively).
These results were confirmed employing SB 202190 $(10 \mu \mathrm{mol} / \mathrm{L})$, which is other selective p38 MAPK inhibitor (Fig. 2A). As RSK can be phosphorylated by p38 MAPK indirectly on tyrosine 529 residue (Czaplinska et al. 2014), and then we also evaluated the levels of phospho-tyrosine RSK after PTHrP treatment in the absence or presence of the p38 MAPK inhibitors SB2 $03580(20 \mu \mathrm{mol} / \mathrm{L})$ and SB $202190(10 \mu \mathrm{mol} / \mathrm{L})$ and the results obtained exclude the possibility that p38 MAPK contributes to RSK activation through the phosphorylation of its tyrosine residues (Fig. 2B). Taken together, these findings suggest that PTHrP increases RSK phosphorylation through ERK1/2 signaling pathway but not via p38 MAPK signaling pathway in both tumor intestinal cell lines.

\section{PTHrP induces nuclear localization of activated RSK in tumor intestinal cells}

Activated RSK proteins remain associated with the membrane, remain in the cytosol or translocate to the nucleus, and therefore, can phosphorylate substrates throughout the cell (Anjum \& Blenis 2008). The translocation to the nucleus correlates with the induction of immediate-early gene expression (Chen et al. 1992). As the regulation of subcellular localization is important for the function of RSK (Gao et al. 2012), we investigated the subcellular distribution of this kinase in cells exposed to PTHrP for 1 and $4 \mathrm{~h}$. We observed that under basal conditions, activated RSK localized in both, cytosolic and nuclear compartments and that after PTHrP treatment, the amount of the activated enzyme increased in the nuclear fraction of Caco2 cells and HCT 116 cells (Fig. 3, top panel and bottom panel, respectively) suggesting that
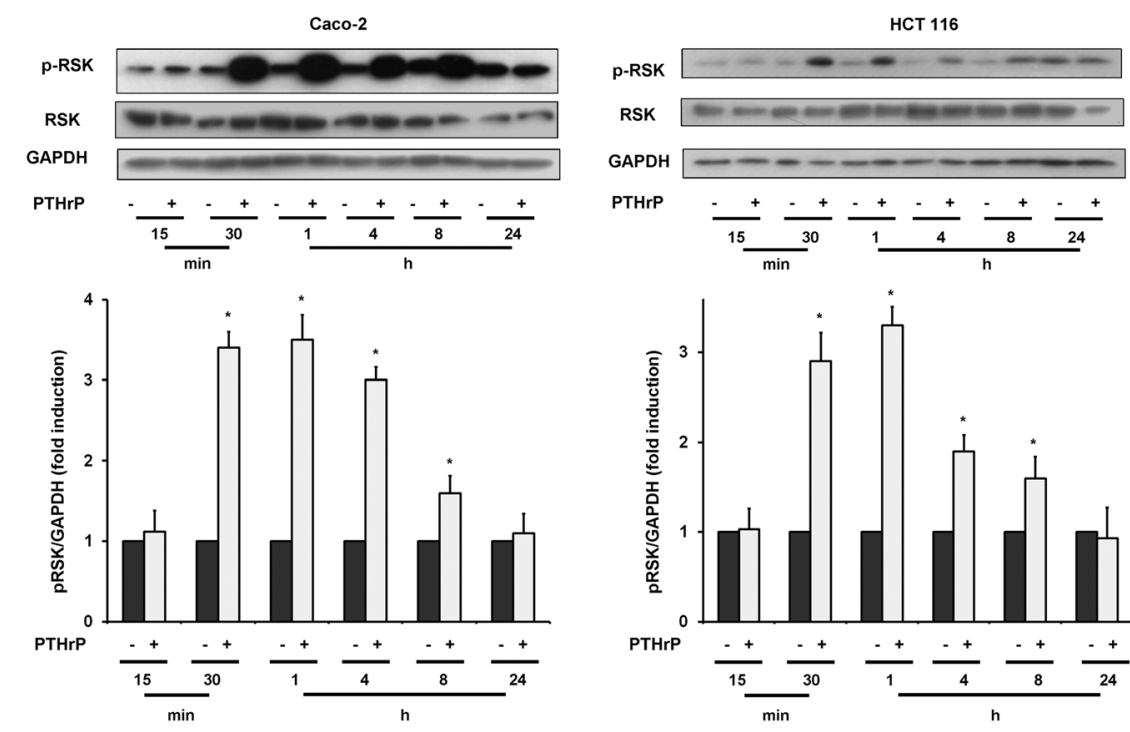

Figure 1

Effects of PTHrP on RSK phosphorylation.

Caco2 cells and HCT116 cells were treated with or without PTHrP (1-34) 10-8 mol/L for different

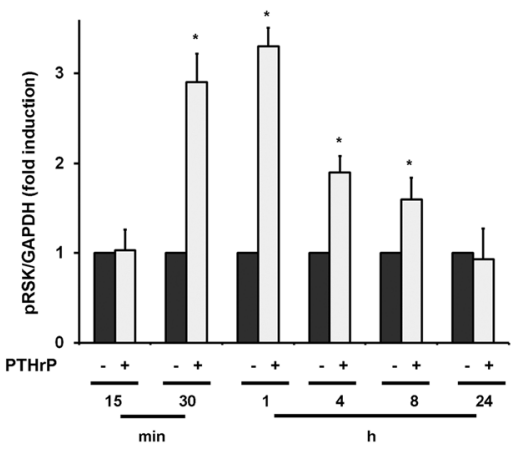
intervals ( 15 and $30 \mathrm{~min}$ and 1, 4, 8 and $24 \mathrm{~h}$ ) as shown in left and right panels, respectively. Western blot analysis of cell lysates was carried out using an anti-phospho RSK antibody. Total RSK $1 / 2 / 3$ was measured in the same immunoblot by stripping the membrane and re-incubating with anti-RSK $1 / 2 / 3$ antibody. The membranes were stripped and reblotted with anti-GAPDH antibody to ensure the equivalence of protein loading. Representative immunoblots and the quantification by scanning densitometry of three independent experiments are shown; means \pm S.D. are given. ${ }^{*} P<0.05$. 
A

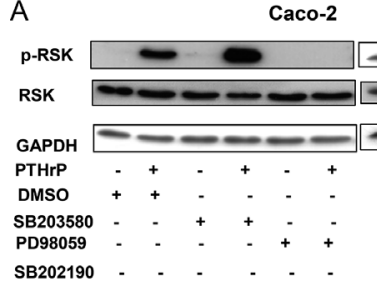

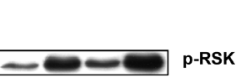

$-\infty \mathrm{RSK}$
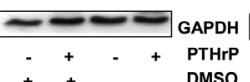
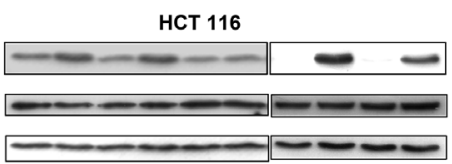

B IP: anti-RSK1/2/3 IB: anti-phospho tyrosine RSK1/2/3 IgG PTHrP DMSO SB203580 SB202190

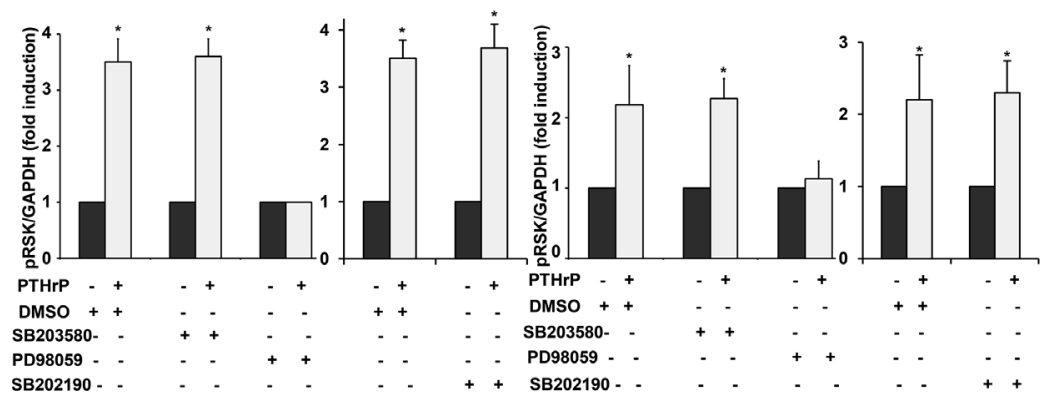

(

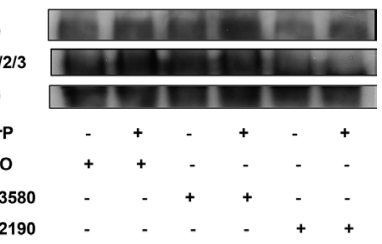

Figure 2

Involvement of ERK1/2 but not of p38 MAPK signaling in PTHrP-dependent RSK phosphorylation. (A) Cells were pre-incubated with MEK inhibitor PD $98059(20 \mu \mathrm{mol} / \mathrm{L})$ or p38 MAPK inhibitors (SB 203580, $20 \mu \mathrm{mol} / \mathrm{L}$ or SB $202190,10 \mu \mathrm{mol} / \mathrm{L}$ ), and then treated with or without PTHrP $10^{-8} \mathrm{~mol} / \mathrm{L}$ for $1 \mathrm{~h}$. Western blot analysis of cell lysates was carried out using an anti-phospho RSK antibody. Total RSK1/2/3 was measured in the same immunoblot by stripping the membrane and re-incubating with anti-RSK1/2/3 antibody. The membranes were stripped and reblotted with anti-GAPDH antibody to ensure the equivalence of protein loading. Representative immunoblots and the quantification by scanning densitometry of three independent experiments are shown; means \pm S.D. are given ( $\left.{ }^{*} P<0.05\right)$. Caco2 cells and HCT 116 cells are shown in left and right panels, respectively. (B) Tumor intestinal cells were exposed to PTHrP $\left(10^{-8} \mathrm{~mol} / \mathrm{L}\right)$ for $1 \mathrm{~h}$ in the presence or absence of the p38 MAPK inhibitors SB 203580 (20 $\left.\mu \mathrm{mol} / \mathrm{L}\right)$ or SB 202190 $(10 \mu \mathrm{mol} / \mathrm{L})$. Then, in cell lysates RSK was immunoprecipitated with anti-RSK1/2/3 antibody, resolved onto SDS-PAGE gels and immunoblotted with anti-phospho tyrosine antibody. The membranes were dyed using Coomassie brilliant blue to demonstrate equal loading.

the hormone induces nuclear localization of activated RSK in tumor intestinal cells. Also, in the same figure, the immunoblots showing protein levels of total RSK revealed that in both cell lines, the treatment with PTHrP for $1 \mathrm{~h}$ increases total nuclear RSK. Taken together, these results indicates that, at least at $1 \mathrm{~h}$ of hormone exposure, the increase of phospho-RSK in the nucleus may be due to the fact that the enzyme is phosphorylated in the nucleus and/or is translocated to the nucleus.

\section{The effects of PTHrP on cell proliferation and in the expression of cyclin D1, CDK6 and p53 are dependent on the ERK/ RSK signaling pathway}

We previously reported that PTHrP increases the expression of cyclin D1 and CDK6, two cell cycle regulatory proteins, which are essential for cell cycle progression, and diminishes the amount of $\mathrm{p} 53$, a negative cell cycle regulator, via ERK1/2, p38 MAPK and PI3K signaling pathways in tumor intestinal cells (Calvo et al. 2014, Martín et al. 2014). It has been shown that RSK is involved in the regulation of cell cycle progression and cell proliferation (Lara et al. 2013). Based on these previous findings and as we observed that PTHrP induced the phosphorylation of RSK through ERK 1/2 signaling pathway in tumor intestinal cells, we first perform experiments employing trypan blue dye exclusion assay to confirm that RSK regulates cell proliferation in these cells treated with PTHrP. To that end, Caco2 cells were pre-incubated with a specific inhibitor of RSK, SL0101 $(50 \mu \mathrm{mol} / \mathrm{L})$ and then treated for 5 days with PTHrP. As shown Fig. 4A, counting live cells in a Neubauer chamber by means of trypan blue dye exclusion revealed that Caco2 cells response to PTHrP was partially abolished in the presence of RSK inhibitor. We selected this time of treatment because in previous studies we observed that the maximum response in cell proliferation is achieved at 5 days of PTHrP exposure in Caco2 cells (Martin et al. 2014). In addition, we observed that the combination of the inhibitor of RSK, SL0101 $(50 \mu \mathrm{mol} / \mathrm{L})$, with the chemotherapeutic drug 5-fluorouracil (5-FU) $(100 \mu \mathrm{M})$ potentiated the inhibition of cell growth observed in tumor intestinal cells treated with 5-FU alone (Fig. 4A).

Then, we investigated the role of this kinase in cell cycle progression induced by PTHrP. To that end, Caco2 cells were pretreated with SL0101 $(50 \mu \mathrm{mol} / \mathrm{L})$, and then incubated with PTHrP for 1 and $24 \mathrm{~h}$. Western blot analysis revealed that the effect of PTH analog on p53, cyclin D1 and CDK6 protein levels is reversed by the RSK inhibitor, suggesting that PTHrP-mediated expression of these cell

Published by Bioscientifica Ltd 
Caco-2

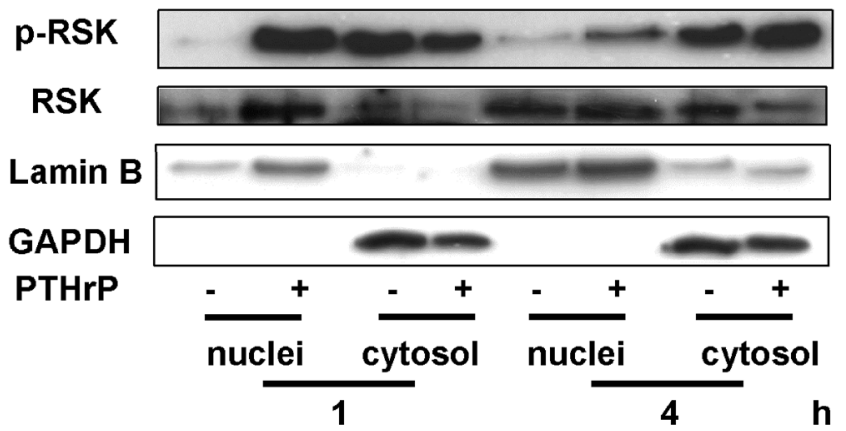

HCT 116

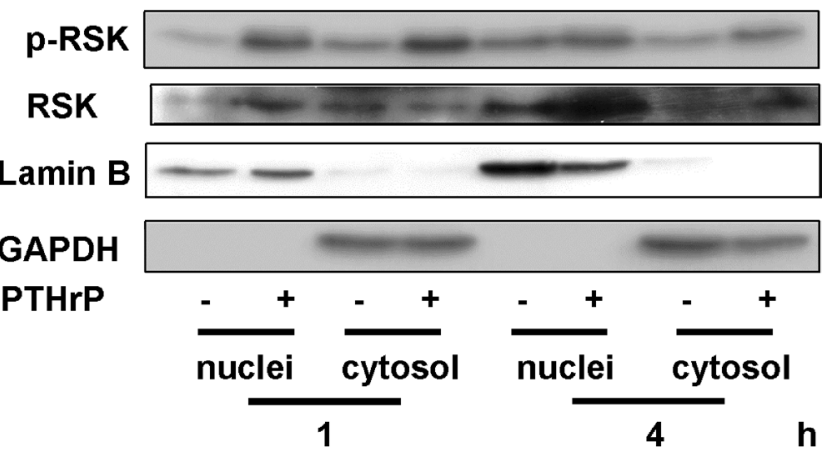

Figure 3

PTHrP induces nuclear localization of activated RSK in tumor intestinal cells. Cells were treated with or without PTHrP (10-8 $\mathrm{mol} / \mathrm{L})$ during 1 and $4 \mathrm{~h}$. Then, the nuclei and cytosolic fractions were isolated and the proteins were analyzed by Western blotting with an anti-phospho RSK antibody. Total RSK1/2/3 was measured in the same immunoblot by stripping the membrane and re-incubating with anti-RSK1/2/3 antibody. Anti-Lamin B and anti-GAPDH antibodies were included to check the purity of nuclear and cytosolic fractions, respectively. Representative immunoblots are shown. Caco2 cells and HCT 116 cells are shown in top panel and bottom panels, respectively.

cycle regulatory proteins is dependent, at least in part, on ERK/RSK signaling pathway in tumor intestinal cells (Fig. 4B and C). According to the results showed in Fig. 1, in Fig. 4B we also observed an increment of phosphoRSK at $1 \mathrm{~h}$ of PTHrP treatment, whereas the levels of total RSK were not different in all experimental conditions in Fig. 4B as well as Fig. 4C.

\section{PTHrP enhances tumor intestinal cell migration through ERK/RSK signaling pathway but not via p38 MAPK}

It has been demonstrated that MAPK activity is also essential for cell migration (Huang et al. 2004). Also, there is increasing evidence indicating that RSK is strongly implicated in cell motility (Czaplinska et al. 2014). In order to obtain further investigation of the functional consequences of RSK activated by PTHrP, we assessed whether the hormone induces changes on migration behavior of tumor intestinal cells employing two methods: wound healing assay and transwell migration assay. A scratch was performed in culture of confluent Caco 2 cells using a $10 \mu \mathrm{L}$ pipette tip and then we observed the wound healing to compare the migration between untreated cells and cells treated with PTHrP. Representative photographs, taken at time points $0,4,24$ and $48 \mathrm{~h}$ of the identical location and the quantification of the results of three separate experiments are shown in Fig. 5A. While under all conditions a closing of the wound was observed, a significant enhancement in wound closure was detected in cells exposed to PTHrP compared to control values at $24 \mathrm{~h}$ with a maximal effect at $48 \mathrm{~h}$. As the wound-healing assay is a method that measures combined effects on cell migration and proliferation, then we performed a transwell migration assay to exclude the contribution in the measurements due to proliferative effects. Caco2 cells and HCT 116 cells were cultivated on $8 \mu \mathrm{m}$ pore size filters in a 24-well culture plate with the same conditions as used for the wound healing assay. Migrated cells were found under all conditions, but a significant increase in migration was evidenced after stimulation with PTHrP for $24 \mathrm{~h}$ in Caco 2 cells and for $18 \mathrm{~h}$ in HCT 116 cells compared to control values (Fig. 5B, left panel and right panel, respectively). These results indicate that PTHrP enhances migration of these tumor intestinal cells.

To gain insight into the signaling events that link PTHrP to cell migration process and to analyze whether MAPK and RSK are involved in PTHrP-stimulated motility, cells were pretreated with MAPK inhibitors or with the inhibitor of RSK, SL0101 $(50 \mu \mathrm{mol} / \mathrm{L})$ and then treated with PTHrP followed by transwell migration assays. As shown in Fig. 5C, ERK1/2 and RSK inhibitors prevented the effect of PTHrP on cell migration, whereas p38 MAPK inhibitor did not reverse the response of Caco2 cells and HCT116 cells to the hormone (left panel and right panel, respectively). These results were confirmed employing SB $202190(10 \mu \mathrm{mol} / \mathrm{L})$, which is other selective p38 MAPK inhibitor (data not shown). Taken together, these results suggest that effect of PTHrP on cell migration is dependent on ERK $1 / 2$ and RSK activation but is independent of the p38 signaling pathway.

\section{PTHrP increases the protein expression of FAK via ERK1/2 and RSK}

The focal adhesion kinase (FAK) is a tyrosine kinase that localizes in focal adhesions acting as a regulator of cell migration (Provenzano \& Keely 2009). For further clarification of the mechanisms and the molecular effectors

Published by Bioscientifica Ltd 
A
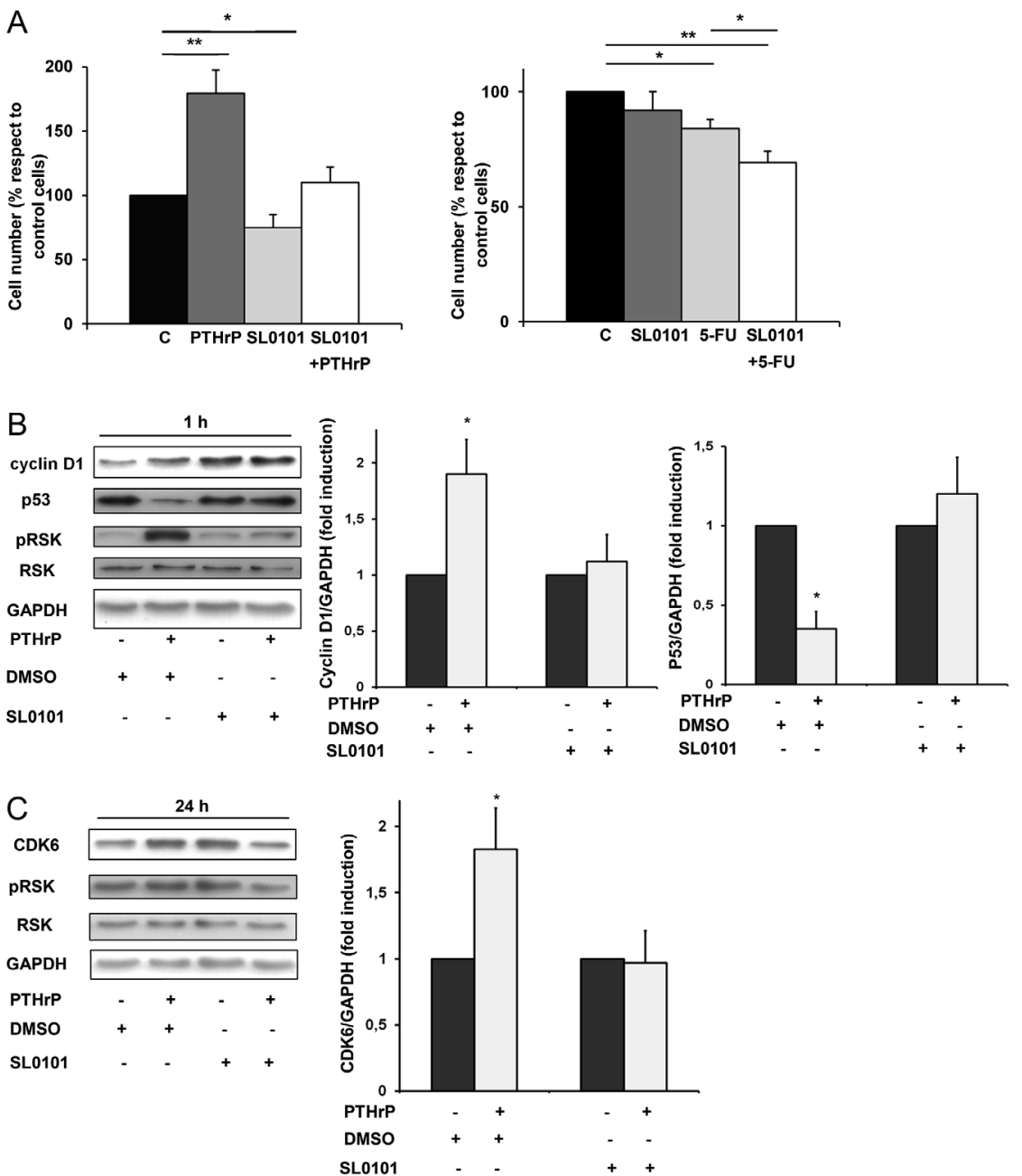

that may be involved in PTHrP regulation of tumor intestinal cells migration, we evaluated the expression of FAK after PTHrP treatment for $15 \mathrm{~min}$ to $24 \mathrm{~h}$. As shown in Fig. 6, western blot analysis revealed that PTHrP increased the protein levels of FAK in both Caco2 cells and HCT116 cells (left and right panel, respectively). The maximal stimulation was achieved at $1 \mathrm{~h}$ and declined at $24 \mathrm{~h}$ of treatment with the peptide.

To investigate the involvement of RSK and MAP kinases in the upregulation of FAK expression induced by PTHrP, cells were pre-incubated in the presence or absence of the RSK or MAPKs inhibitors and then treated with or without PTHrP. Figure 7, top panel showed that in Caco2 cells RSK and ERK1/2 inhibitor reversed FAK upregulation induced by the hormone, whereas p38 MAPK inhibitor did not reverse PTHrP effect. Similar results were observed in HCT116 cells (Fig. 7, bottom panel), suggesting that PTHrP increases FAK protein expression via ERK1/2-RSK signaling pathway in both tumor intestinal cell lines. We also evaluated the protein levels of FAK after PTHrP

\section{Figure 4}

Effects of RSK on cell proliferation and in the expression changes of cell cycle regulatory proteins by PTHrP. (A, left panel) $\mathrm{CacO} 2$ cells were pre-incubated with or without RSK inhibitor SL0101 $(50 \mu \mathrm{mol} / \mathrm{L})$ for $30 \mathrm{~min}$ and then treated with PTHrP for 5 days. Cells were counted using Trypan blue dye. Results are the average of three independent experiments. The effects of each treatment have been compared with the control (untreated cells). The control has been set to $100 \%$. The data shown are the average of cell number of three independent experiments. $* * P<0.01, * P<0.05$ with respect to the corresponding control. (A, right panel) $\mathrm{Caco} 2$ cells were incubated with or without RSK inhibitor SL0101 $(50 \mu \mathrm{mol} / \mathrm{L})$ in the presence or absence of 5 -FU for $24 \mathrm{~h}$. Then, cells were counted using Trypan blue dye. Results are the average of three independent experiments. ${ }^{*} P<0.05, * * P<0.025$ with respect to the corresponding control. (B) and (C) $\mathrm{Caco} 2$ cells were pre-incubated for $30 \mathrm{~min}$ with SL0101 $(50 \mu \mathrm{mol} / \mathrm{L})$, an inhibitor of RSK, and then exposed to PTHrP (10-8 $\mathrm{mol} / \mathrm{L})$ for 1 or $24 \mathrm{~h}$ followed by Western blot analysis of proteins from cell lysates using anti-phospho RSK, anti-RSK 1/2/3, anti-cyclin D1, anti-CDK6 or anti-p53 antibodies. Blotted membranes were reprobed with anti-GAPDH antibody. Representative immunoblots and the quantification by scanning densitometry of 3 independent experiments are shown; means \pm S.D. are given. ${ }^{*} P<0.05$ with respect to the control. treatment in the absence or presence of SB 202190 $(10 \mu \mathrm{mol} / \mathrm{L})$, which is other selective p38 MAPK inhibitor and the results obtained exclude totally the possibility that p38 MAPK participates in the upregulation of FAK expression induced by PTHrP (Fig. 7).

\section{PTHrP activates RSK in xenografts tumor}

In view of the results observed in both Caco2 cells and HCT116 cells, the next objective was to investigate whether the hormone also activates RSK in colorectal tumor tissues. Nude mice xenografts of HCT116 cells were established to investigate PTHrP effects in vivo as it has been shown that these cells are tumorigenic in nude mice its tumorigenic capacity being much greater than that of Caco2 cells (Dunn et al. 2011). Immunohistochemistry analysis of these xenografts tumor showed increased levels of p-RSK in tumors treated with PTHrP with respect to the levels observed in tumor treated with PBS, which is the vehicle of the hormone (Fig. 8).

Published by Bioscientifica Ltd. 
A

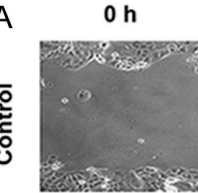

$4 \mathrm{~h}$

$24 \mathrm{~h}$

$48 \mathrm{~h}$

巠
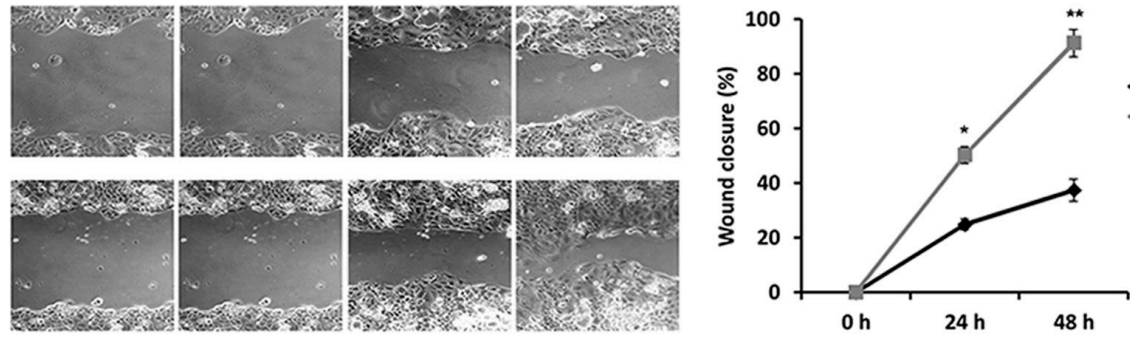

$\rightarrow$ CONTROL

를-PTHrP

B

Caco-2
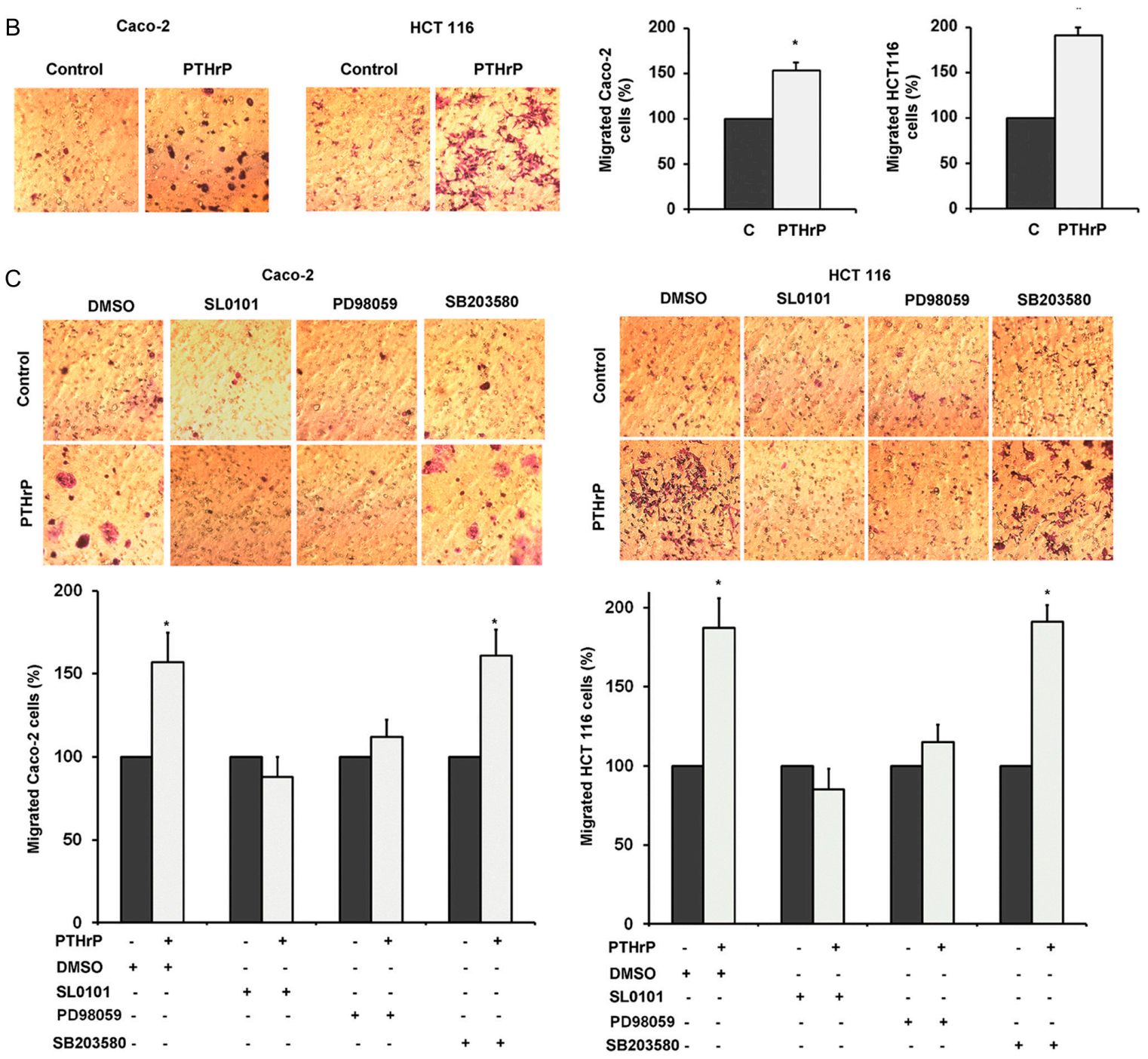

Figure 5

The migration of Caco2 cells and HCT 116 cells is increased by PTHrP. (A) Representative phase micrographs of Caco2 tumor intestinal cells treated with or without PTHrP $10^{-8} \mathrm{~mol} / \mathrm{L}$ at various times after monolayer wounding and the quantification of the results expressed as percentage of wound closure relative to control are shown. (B) Transwell migration assay. Cells were treated in the presence or absence of PTHrP $10^{-8} \mathrm{~mol} / \mathrm{L}$, fixed with methanol and stained with violet crystal. The migrated cells were counted, and the quantification of the results expressed as percentage of migrated cells relative to control is shown. Data are representative of three independent experiments performed in triplicate. ${ }^{*} P<0.05$. Caco2 cells and HCT 116 cells are shown in left and right panels, respectively. (C) Involvement of ERK1/2 and RSK but not of p38 MAPK in tumor intestinal cells migration induced by PTHrP.

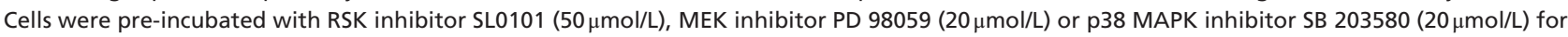
$30 \mathrm{~min}$, treated with or without PTHrP $10^{-8} \mathrm{~mol} / \mathrm{L}$ and the cell migration was evaluated using a transwell migration assay. Cells were fixed with methanol and stained with violet crystal. The migrated cells were counted and the quantification of the results expressed as percentage of migrated cells relative to control is shown. Data are representative of three independent experiments performed in triplicate. ${ }^{*} P<0.05$. Caco2 cells and HCT 116 cells are shown in left and right panels, respectively.

http://jme.endocrinology-journals.org DOI: 10.1530/JME-16-0216
๑ 2017 Society for Endocrinology Printed in Great Britain
Published by Bioscientifica Ltd 

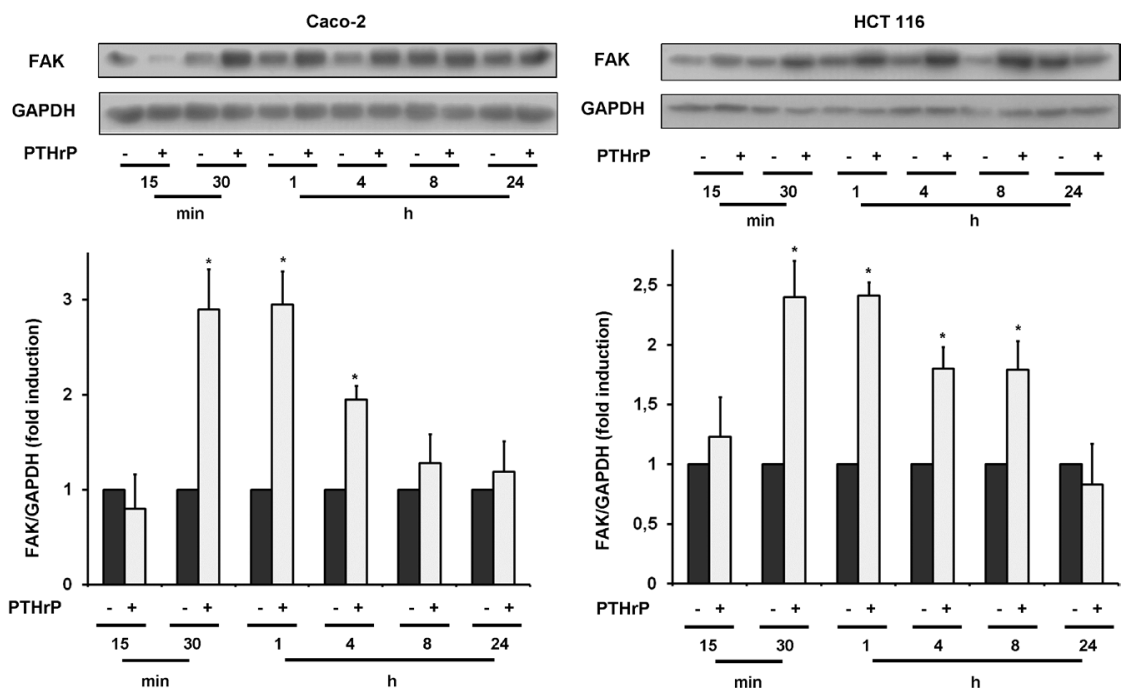

\section{Figure 6}

PTHrP increases the protein expression of FAK. Cells were incubated in serum-free DMEM for $24 \mathrm{~h}$ and then treated with or without PTHrP $10^{-8} \mathrm{~mol} / \mathrm{L}$ for different intervals ( 15 and $30 \mathrm{~min}$ and 1, 4, 8 and 24h). Proteins from lysates were prepared as described in 'Methods' section, separated on $8 \%$ SDS-PAGE, and immunoblotting using anti-FAK antibody. In order to evaluate the equivalence of protein content among the different experimental conditions, blotted membranes were reprobed with anti-GAPDH antibody. Representative immunoblots and the quantification by scanning densitometry of three independent experiments are shown; means \pm S.D. are given. ${ }^{*} P<0.05$, with respect to the corresponding control. Caco2 cells and HCT 116 cells are shown in left and right panels, respectively.

\section{Discussion}

PTHrP was found to be expressed in numerous types of cancer (McCauley \& Martin 2012) and in more than 90\% of colon cancer patients (Soki et al. 2012). Differences in its prognostic applicability may reflect temporal aspects and/or downstream events that have been difficult to elucidate in the context of cancer. Moreover, PTHrP is a polyhormone with multiple biologically active domains, which may explain the variability seen in cancer prognosis and the necessity to further elucidate PTHrP actions in cancer. Alternative splicing and posttranslational proteolysis generate different PTHrP isoforms and fragments that can elicit various cellular responses. The variety of PTHrP fragments and different actions (autocrine, paracrine, endocrine and intracrine) portrays the complexity of PTHrP-induced responses. PTHrP can participate in cell autonomous processes such as tumor cell cycle progression, apoptosis, survival and migration, by the regulation of different signaling pathways, which enhance the capacity for tumor growth and dissemination (Sourbier \& Massfelder 2006).

Recently, we obtained evidence that in Caco2 cells, a cell line from human colorectal adenocarcinoma, exogenous PTHrP (1-34) increases cell proliferation,
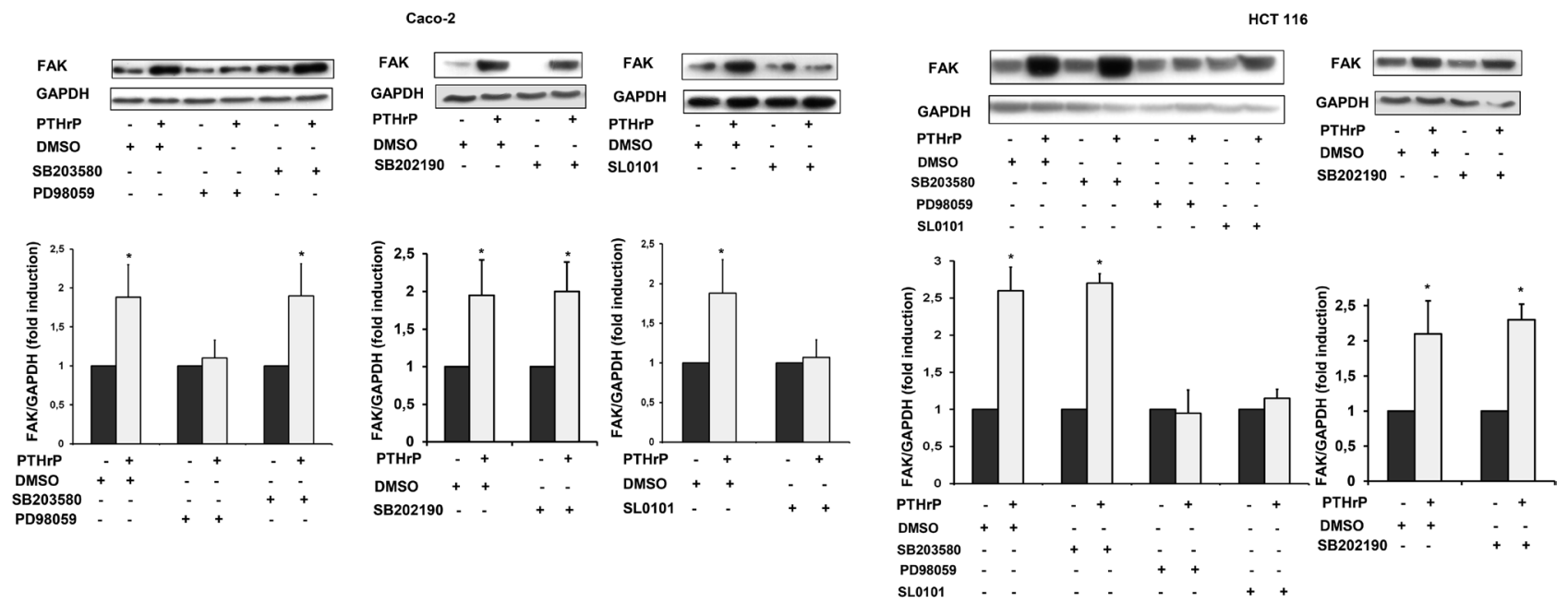

Figure 7

PTHrP increases the protein expression of FAK via ERK1/2 and RSK but not through p38MAPK. Cells were pre-incubated for $30 \mathrm{~min}$ with SL0101 $(50 \mu \mathrm{mol} / \mathrm{L})$, PD $98059(20 \mu \mathrm{mol} / \mathrm{L})$, SB $203580(20 \mu \mathrm{mol} / \mathrm{L})$ or SB $202190(10 \mu \mathrm{mol} / \mathrm{L})$ and then exposed to PTHrP $10^{-8} \mathrm{~mol} / \mathrm{L}$ followed by Western blot analysis of proteins from cell lysates using anti-FAK antibody. Blotted membranes were re-probed with anti-GAPDH antibody. Representative immunoblots and the quantification by scanning densitometry of three independent experiments are shown; means \pm s.D. are given. ${ }^{*} P<0.05$ with respect to the control. Caco2 cells and HCT 116 cells are shown in top panel and bottom panels, respectively.

http://jme.endocrinology-journals.org DOI: 10.1530/JME-16-0216
(C) 2017 Society for Endocrinology Printed in Great Britain
Published by Bioscientifica Ltd 

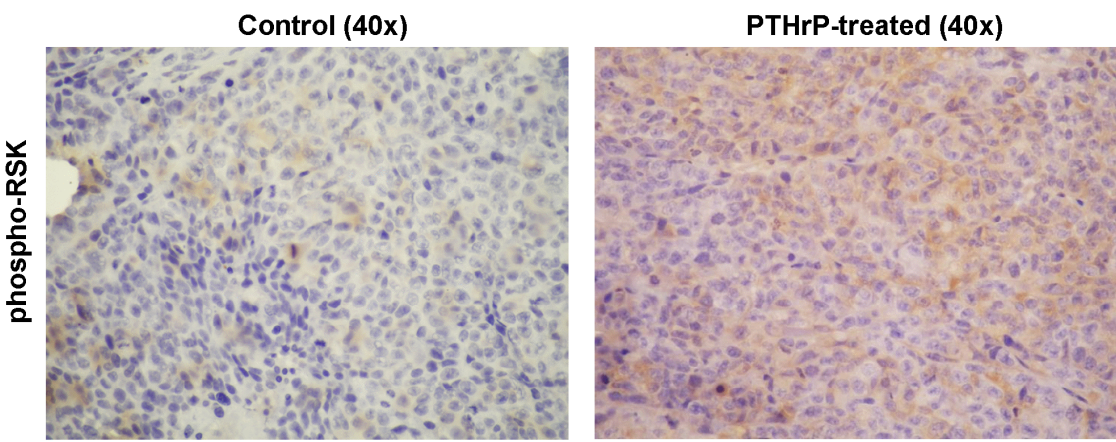

Figure 8

PTHrP activates RSK in vivo. HCT 116 xenograft tumors removed from nude mice were analyzed by immunohistochemistry. Tumor sections were stained with anti-pRSK antibody. Images are from tumor treated with PTHrP (right) and tumor untreated (left).

promotes cell cycle progression and exerts a protective effect under apoptotic conditions via ERK1/2 and p38 MAPK (Lezcano et al. 2013, Calvo et al. 2014, Martin et al. 2014).

A huge variety of intracellular and extracellular signaling molecules have been implicated in colon cancer. In the intracellular signaling networks, one of the most fundamental pathways is the mitogen-activated protein kinase (MAPK) cascades. The best known are the extracellular signal-regulated kinases (ERK1/2); the c-Jun $\mathrm{N}$-terminal or stress-activated protein kinases (JNK or SAPK) and p38 MAPK (Huang et al. 2004). Activation of ERK1/2 signaling is very common in colon cancer (Setia et al. 2014). It has been reported that small molecular inhibitors targeting ERK signaling have shown anti-tumor effects on the colon cancer (Peng et al. 2013). However, mutations of core components in the ERK signaling pathway have been observed in samples, which lead to the drug resistance (Hirschi et al. 2014, Mori et al. 2015). Thus, the study of target of the ERK signaling will facilitate the development of drugs. Recently we observed that PTHrP induces the phosphorylation/activation of ERK $1 / 2$ and $\alpha$ p38 MAPK in Caco2 cells and HCT 116 cells (Martin et al. 2014, Martin et al. unbulished work). Therefore, we propose to further delineate the molecular mechanism involved in tumor intestinal cells with response to PTHrP.

MAPKs phosphorylate and activate downstream protein kinases such as the ribosomal S6 kinase (RSK) that can target proteins involved in cell cycle progression and cell migration (Lara et al. 2013). RSKs kinases emerge as potential therapeutic targets in various types of human cancer (Romeo et al. 2012, Lara et al. 2013, Sulzmaier \& Ramos 2013). In this work, we proposed to address whether PTHrP modulates RSK phosphorylation status in Caco2 and HCT 116 cells. To that end, we used an antibody that recognizes RSK1 and RSK2 isoforms with their residues phosphorylated on threonine 359 and serine 363. The function of the different isoforms and their subcellular localization vary depending on cell system. The results presented indicate that in these tumor intestinal cells, PTHrP increases the phosphorylation of RSK via ERK1/2. Several studies show that RSK2 promotes the prometastatic function of ERK1/2 (Lara 2013), whereas RSK1 and RSK4 isoforms may have the opposite role in lung cancer (Lara 2011). The fibroblast growth factor increases the phosphorylation of RSK2 on tyrosine 529 indirectly through the p38 MAPK pathway in breast adenocarcinoma cells, regulating the formation of focal adhesions and cell migration. This activation by p38 MAPK possibly facilitated the phosphorylation mediated by ERK1/2 in threonine 359 and serine 363 (Czaplinska et al. 2014). In contrast to these observations, our results suggest that the phosphorylation of RSK induced by PTHrP in these tumor intestinal cells is independent of p38 MAPK.

Activated RSK proteins remain associated with the membrane, remain in the cytosol or translocate to the nucleus, and therefore, can phosphorylate substrates throughout the cell (Anjum \& Blenis 2008). Chen and coworkers (Chen et al. 1992) demonstrated that a fraction of activated RSKs enter to the nucleus. Moreover, the regulation of subcellular localization is important for the function of RSK (Gao et al. 2012). In line with these observations, our results show that, in $\mathrm{Caco} 2$ cells and HCT 116 cells, PTHrP induces the nuclear localization of activated RSK.

RSKs have been involved in the regulation of cell cycle in various malignancies through indirect (modulation of transcription factors) or direct effects on the cell-cycle machinery (Lara et al. 2013). RSK phosphorylates serum response factor (SRF) and contributes to the transcriptional activation of c-FOS. Activation of c-FOS results in the activation of cyclin D1, promoting G1-S phase progression (Anjum \& Blenis 2008). RSK phosphorylates and inhibits glycogen synthase kinase (GSK3), which has been suggested to promote stabilization of cyclin D1 and MYC, resulting in cell cycle progression and cell survival (Anjum \& Blenis 2008). However, the roles of RSKs in cell cycle progression of colon cancer cells still remain

Published by Bioscientifica Ltd. 
unclear. In this study, we provide evidence that ERK/RSK signaling pathway is involved in cell proliferation and cell cycle progression of tumor intestinal cells induced by PTHrP, regulating the expression of cell cycle regulatory proteins. In line with our observations, in the breast cancer cell line MCF-7, inhibition of RSKs using the paninhibitor SL-0101 arrests the cell cycle in $\mathrm{G}_{1}$ by preventing the expression of cyclin D1 (Smith et al. 2005).

It has been reported that PTHrP overexpressed in LoVo cells increases the migration of these human colon tumor cells (Shen et al. 2007). This experimental model is used to evaluate mainly an autocrine and/or intracrine action of endogenously expressed PTHrP; however, until now, it was unknown whether exogenous PTHrP could regulate, through a paracrine pathway, the migration of intestinal tumor cells. Using wound healing and transwell migration assays, we now demonstrate, and for the first time, that exogenous PTHrP also increases the migration of Caco 2 cells and HCT 116 cells. In agreement with our findings, PTHrP modulates the migration of bone and breast tumor cells (Shen et al. 2004, Mak et al. 2013).

Several lines have implicated the importance of ERK signaling pathway in cancer cell migration (Davies et al. 2014, Li et al. 2014, Zhang et al. 2014, Sever \& Brugge 2015). The present study shows that in Caco 2 and HCT 116 cells, ERK1/2 inhibition prevented the effect of PTHrP on cell migration, indicating that the hormone regulates this process through an ERK1/2-dependent pathway. According to our results, activation of the ERK1/2 cascade by galectin-3 promotes colon cancer cell migration (Wu et al. 2013). Moreover, ERK1/2 signaling pathway has been involved in the migration of the colon cancer cell SW620 induced by TF/FVIIa/PAR2 (Guo et al. 2011). p38 MAPK has also been implicated in the movement of various cell types (Ray et al. 2003, Yu et al. 2004, An et al. 2015, Lv et al. 2015, Yang et al. 2015). However, here we show that the migration of tumor intestinal cells induced by PTHrP is independent of p38 MAPK pathway.

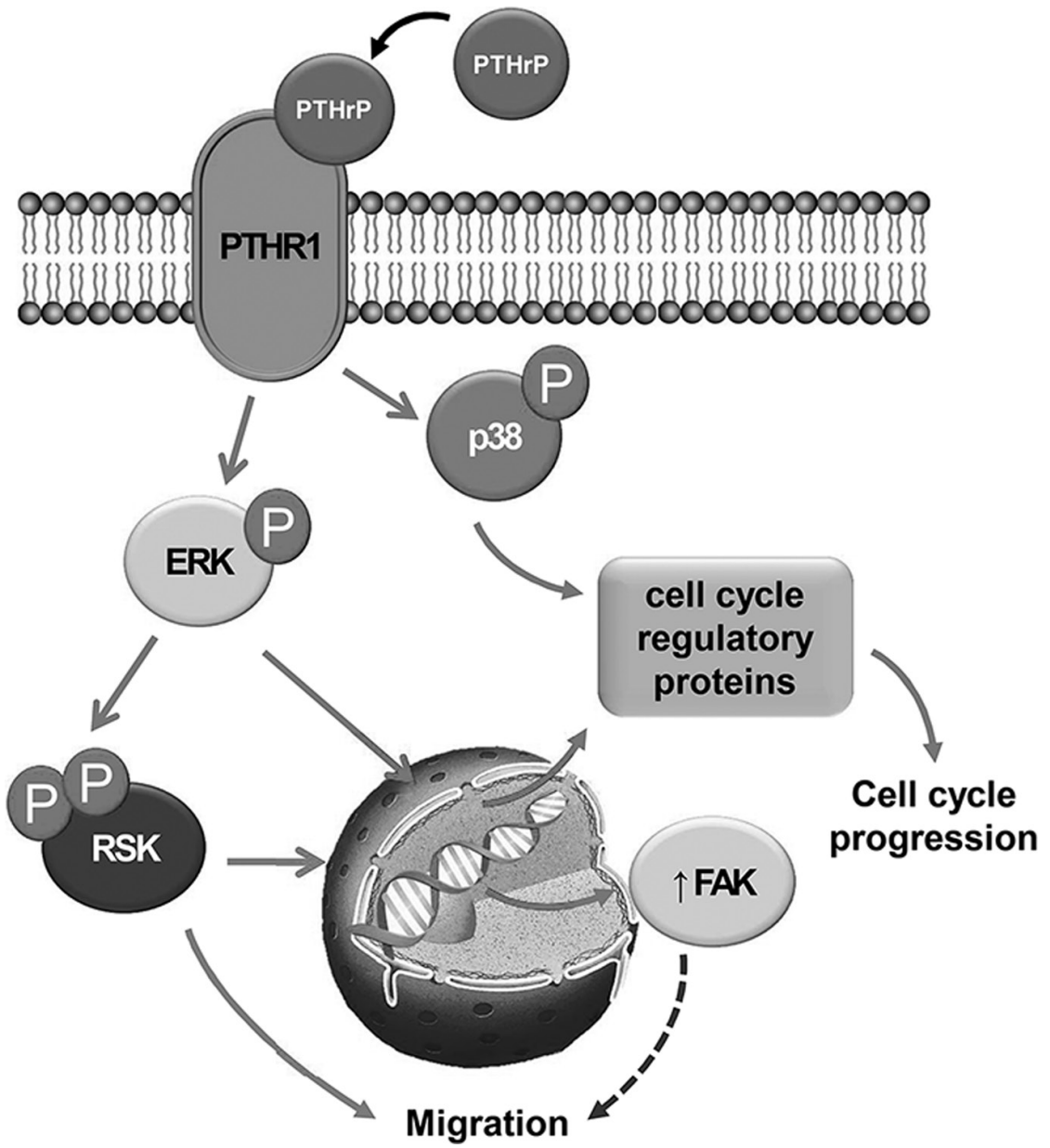

Figure 9

Signal transduction pathways associated with the migration and cell cycle progression of human colon cancer cells induced by exogenous PTHrP. http://jme.endocrinology-journals.org DOI: 10.1530/JME-16-0216
๑ 2017 Society for Endocrinology Printed in Great Britain 
RSK signaling is involved in the regulation of cell migration (Zhou et al. 2015). Using an inhibitor of RSK, SL0101, we observed that RSK is implicated in cell migration of Caco2 cells and HCT 116 cells induced by PTHrP. In line with our observations, among RSK family members, RSK1 and RSK2 have been reported to promote cancer cell motility in various cancer cell types, including head and neck squamous cell carcinoma, colon adenocarcinoma and prostate cancer cell lines, through cancer-specific mechanisms (Doehn et al. 2009, Kang et al . 2010, Gawecka et al. 2012).

Cell migration is a highly coordinated complex process that involves the reorganization of the actin cytoskeleton, formation of plasma membrane projections and turnover of cell adhesions. The focal adhesion kinase (FAK) is a non-receptor tyrosine kinase that localizes in focal adhesions acting as a regulator of cell migration. This kinase is overexpressed in multiple human cancers, and it is known to be directly involved in the fundamental adhesion and in many growth factor signaling pathways that are relevant in cancer (Provenzano \& Keely 2009). Most studies have focused on understanding the activation of FAK at the posttranslational level. However, increasing evidence demonstrates the importance of small changes in FAK mRNA and protein levels of migrating intestinal epithelial cells (Yu et al. 2000, Basson et al. 2006) and in human colon cancer cells (Nakagawa et al. 1998, Agochiya et al. 1999). So we decided to investigate whether the expression of FAK in our experimental model is modulated by PTHrP and if so, the possible involvement of RSK, ERK1/2 and p38 MAPK in this hormone-induced response. The results showed that the protein expression of FAK is increased in Caco2 cells and HCT 116 cells stimulated with PTHrP through ERK 1/2 and RSK but not via p38 MAPK, suggesting that increased availability of FAK could play a prominent role in the migration process. FAK protein can functionally interact with the MAPK pathways, including ERK1/2 and p38 MAPK, and with RSK (Yu et al. 2000, Walsh et al. 2008). RSK2 is involved in the relocalization of FAK to the focal adhesions (Czaplinska et al. 2014). Recent studies have suggested a role of ERK1/2 as an upstream activator to regulate FAK expression via the transcription factor PEA3 in highly metastatic melanoma cancer cells (Li et al. 2013). On the other hand, in disagreement with our findings, the transforming growth factor-beta stimulates intestinal epithelial FAK synthesis via p38-dependent mechanisms (Walsh et al. 2008). Understanding in the functional interaction between FAK, RSK and MAPKs may provide new insights into the deregulated cell migration that is characteristic of cancer.

\section{Conclusions}

In conclusion, the present investigation provides, to our knowledge, the first direct evidence demonstrating that exogenous PTHrP increases the phosphorylation of RSK via ERK1/2 but not through p38 MAPK signaling pathway in Caco2 cells and HCT 116 cells. The peptide induces the nuclear localization of activated RSK. RSK is involved in cell proliferation and cell cycle progression of tumor intestinal cells induced by PTHrP through the regulation of the expression of cell cycle regulatory proteins. The hormone also increases the migration and the protein expression of FAK via ERK1/2 and RSK but not through p38 MAPK signaling pathway (Fig. 9). In addition, PTHrP activates RSK in xenografts tumor demonstrating the relevance of the results observed from in vitro studies.

Therefore, the results obtained in this study expand our knowledge on the signaling pathways that are involved on Caco2 cells and HCT 116 cells response to PTHrP. RSK could emerge as potential therapeutic target in colon cancer. Furthermore, this work clearly illustrates a specific context in which ERK1/2 and RSK have been shown to play a key role in the stimulation of intestinal tumor cell migration by PTHrP, while p38 MAPK is not involved in this process.

We consider that our findings may provide new insights into the deregulated cell cycle and cell migration that is characteristic of cancer.

\section{Declaration of interest}

The authors declare that there is no conflict of interest that could be perceived as prejudicing the impartiality of the research reported.

\section{Funding}

This work was supported by grants from the Agencia Nacional de Promoción Científica y Tecnológica (ANPCYT) (PICT-2013-1441), Consejo Nacional de Investigaciones Científicas y Técnicas (CONICET) (PIP112201101-00409), Instituto Nacional del Cáncer (Resolución Ministerial 493/14; RESOL-2016-1006-E-APN-MS) and Universidad Nacional del Sur (PGI: 24/B188; PGI: 24/B230), Argentina.

\section{Acknowledgements}

The authors thank Dr Ariel Zwenger for providing us the chemotherapeutic drug 5-FU.
() 2017 Society for Endocrinology Printed in Great Britain
Published by Bioscientifica Ltd 


\section{References}

Agochiya M, Brunton VG, Owens DW, Parkinson EK, Paraskeva C, Keith WN \& Frame MC 1999 Increased dosage and amplification of the focal adhesion kinase gene in human cancer cells. Oncogene 18 5646-5653. (doi:10.1038/sj.onc.1202957)

An C, Sato K, Wu T, Bao M, Bao L, Tobo M \& Damirin A 2015 Extracellular acidification synergizes with PDGF to stimulate migration of mouse embryo fibroblasts through activation of p38MAPK with a PTX-sensitive manner. Biochemical and Biophysical Research Communications 460 191-197. (doi:10.1016/j. bbrc.2015.03.006)

Anjum R \& Blenis J 2008 The RSK family of kinases: emerging roles in cellular signalling. Nature Reviews: Molecular Cell Biology 9 747-758. (doi:10.1038/nrm2509)

Basson MD, Sanders MA, Gomez R, Hatfield J, Vanderheide R, Thamilselvan V, Zhang J \& Walsh MF 2006 Focal adhesion kinase protein levels in gut epithelial motility. American Journal of Physiology: Gastrointestinal and Liver Physiology 291 G491-G499. (doi:10.1152/ajpgi.00292.2005)

Bradford M 1976 A rapid and sensitive method for quantification of microgramquantities of proteins utilizing the principle of protein binding. Analytical Biochemistry 72 248-254. (doi:10.1016/00032697(76)90527-3)

Calvo N, Martín MJ, de Boland AR \& Gentili C 2014 Involvement of ERK1/2, p38 MAPK, and PI3K/Akt signaling pathways in the regulation of cell cycle progression by PTHrP in colon adenocarcinoma cells. Biochemistry and Cell Biology 92 305-315. (doi:10.1139/bcb-2013-0106)

Chan BP, Gomes T, Musselman RP, Auer RC, Moloo H, Mamdani M, Al-Omran M, Boushey RP \& Alobeed O 2012 Trends in colon cancer surgery in Ontario: 2002-2009. Colorectal Disease 14 e708-e712. (doi:10.1111/j.1463-1318.2012.03166.x)

Chen RH, Sarnecki C \& Blenis J 1992 Nuclear localization and regulation of erk- and rsk-encoded protein kinases. Molecular and Cellular Biology 12 915-927. (doi:10.1128/MCB.12.3.915)

Curtin JC 2013 Novel drug discovery opportunities for colorectal cancer. Expert Opinion on Drug Discovery 8 1153-1164. (doi:10.1517/17460441. 2013.807249)

Czaplinska D, Turczyk L, Grudowska A, Mieszkowska M, Lipinska AD, Skladanowski AC, Zaczek AJ, Romanska HM \& Sadej R 2014 Phosphorylation of RSK2 at Tyr529 by FGFR2-p38 enhances human mammary epithelial cells migration. Biochimica et Biophysica Acta 1843 2461-2470. (doi:10.1016/j.bbamcr.2014.06.022)

Davies JC, Tamaddon-Jahromi S, Jannoo R \& Kanamarlapudi V 2014 Cytohesin 2/ARF6 regulates preadipocytemigration through the activation of ERK1/2. Biochemical Pharmacology 92 651-660. (doi:10.1016/j.bcp.2014.09.023)

Doehn U, Hauge C, Frank SR, Jensen CJ, Duda K, Nielsen JV, Cohen MS, Johansen JV, Winther BR, Lund LR, et al. 2009 RSK is a principal effector of the RAS-ERK pathway for eliciting a coordinate promotile/ invasive gene program and phenotype in epithelial cells. Molecular Cell 35 511-522. (doi:10.1016/j.molcel.2009.08.002)

Dunn EF, Iida M, Myers RA, Campbell DA, Hintz KA, Armstrong EA, Li C \& Wheeler DL 2011 Dasatinib sensitizes KRAS mutant colorectal tumors to cetuximab. Oncogene 30 561-574. (doi:10.1038/ onc.2010.430)

Gao X, Chaturvedi D \& Patel TB 2012 Localization and retention of p90 ribosomal S6 kinase 1 inthe nucleus: implications for its function. Molecular Biology of the Cell 23 503-515. (doi:10.1091/mbc.E11-070658)

Gawecka JE, Young-Robbins SS, Sulzmaier FJ, Caliva MJ, Heikklia MM, Matter ML \& Ramos JW 2012 RSK2 suppresses integrin activation and fibronectin matrix assembly and promotes cell migration. Journal of Biological Chemistry 287 43424-43437. (doi:10.1074/jbc. M112.423046)
Guo D, Zhou H, Wu Y, Zhou F, Xu G, Wen H \& Zhang X 2011 Involvement of ERK1/2/NF-kB signal transduction pathway in TF/FVIIa/PAR2-induced proliferation and migration of colon cancer cell SW620. Tumour Biology 32 921-930. (doi:10.1007/s13277-0110194-1)

Hecht SM, Lannigan-Macara DA, Smith JA, O'Doherty GA \& Hilinski MK 2015 Synthesis and identification of novel RSK-specific inhibitors. U Patent 9040673 B2. (available at: http://www.google.com.gi/patents/ US9040673)

Hirschi B, Gallmeier E, Ziesch A, Marschall M \& Kolligs FT 2014 Genetic targeting of BRafV600E affects survival and proliferation and identifies selective agents against BRAF-mutant colorectal cancer cells. Molecular Cancer 13 122. (doi:10.1186/1476-4598-13-122)

Huang C, Jacobson K \& Schaller MD 2004 MAPkinases and cell migration. Journal of Cell Science 117 4619-4628. (doi:10.1242/jcs.01481)

Kang S, Elf S, Lythgoe K, Hitosugi T, Taunton J, Zhou W, Xiong L, Wang D, Muller S, Fan S, et al. 2010 p90 ribosomal S6 kinase 2 promotes invasion and metastasis of human head and neck squamous cell carcinoma cells. Journal of Clinical Investigation 120 1165-1177. (doi:10.1172/JCI40582)

Lara R, Mauri FA, Taylor H, Derua R, Shia A \& Gray C 2011 An siRNA screen identifies RSK1 as a key modulator of lung cancer metastasis. Oncogene 30 3513-3521. (doi:10.1038/onc.2011.61)

Lara R, Seckl MJ \& Pardo OE 2013 The p90 RSK family members: common functions and isoform specificity. Cancer Research $\mathbf{7 3}$ 5301-5308. (doi:10.1158/0008-5472.CAN-12-4448)

Lezcano V, Gentili C \& de Boland AR 2013 Role of PTHrP in human intestinal Caco-2 cell response to oxidative stress. Biochimica et Biophysica Acta: Molecular Cell Research 1833 2834-2843. (doi:10.1016/j.bbamcr.2013.06.029)

Li S, Huang X, Zhang D, Huang Q, Pei G, Wang L, Jiang W, Hu Q, Tan R \& Hua ZC 2013 Requirement of PEA3 for transcriptional activation of FAK gene in tumor metastasis. PLOS ONE 8 e79336. (doi:10.1371/ journal.pone.0079336)

Li Y, Zhang Z, Zhou X, Li L, Liu Q, Wang Z, Bai X, Zhao Y, Shi H, Zhang $\mathrm{X}$, et al. 2014 The oncoprotein HBXIP enhances migration of breast cancer cells through increasing filopodia formation involving MEKK2/ERK1/2/Capn4 signaling. Cancer Letters 355 288-296. (doi:10.1016/j.canlet.2014.09.047)

Lv J, Sun X, Ma J, Ma X, Zhang Y, Li F, Li Y \& Zhao Z 2015 Netrin-1 induces the migration of Schwann cells via p38 MAPK and PI3K-Akt signaling pathway mediated by the UNC5B receptor. Biochemical and Biophysical Research Communications 464 263-268. (doi:10.1016/j. bbrc.2015.06.140)

Maioli E \& Fortino V 2004 The complexity of PTHrP signaling. Cellular and Molecular Life Sciences 61 257-262. (doi:10.1007/s00018-0033233-2)

Mak IW, Turcotte RE \& Ghert M 2013 Parathyroid hormone-related protein (PTHrP) modulates adhesion, migration and invasion in bone tumor cells. Bone 55 198-207. (doi:10.1016/j. bone.2013.02.020)

Martín MJ, Calvo N, de Boland AR \& Gentili C 2014 Molecular mechanisms associated with PTHrP-induced proliferation of colon cancer cells. Journal of Cellular Biochemistry 115 2133-2145. (doi:10.1002/jcb.24890)

McCauley LK \& Martin TJ 2012 Twenty-five years of PTHrP progress: from cancer hormone to multifunctional cytokine. Journal of Bone and Mineral Research 27 1231-1239. (doi:10.1002/jbmr.1617)

Mori Y, Nagasaka T, Mishima H, Umeda Y, Inada R, Kishimoto H, Goel A \& Fujiwara T 2015 The rare BRAF VK600-601E mutation as a possible indicator of poor prognosis in rectal carcinoma-a report of a case. BMC Medical Genetics 16 1. (doi:10.1186/s12881-015-0144-7)

Nakagawa K, Sogo S, Hioki K, Tokunaga R \& Taketani S 1998 Acquisition of cell adhesion and induction of focal adhesion kinase of human colon cancer Colo 201 cells by retinoic acid induced differentiation. Differentiation 62 249-257. (doi:10.1046/j.1432-0436.1998.6250249.x) 
Park YS \& Cho NJ 2012 EGFR and PKC are involved in the activation of ERK1/2 and p90 RSK and the subsequent proliferation of SNU-407 colon cancer cells by muscarinic acetylcholine receptors. Molecular and Cellular Biochemistry 370 191-198. (doi:10.1007/s11010-0121410-z)

Peng H, Dara L, Li TW, Zheng Y, Yang H, Tomasi ML, Tomasi I, Giordano P, Mato JM \& Lu SC 2013 MAT2B-GIT1 interplay activates MEK1/ERK 1 and 2 to induce growth in human liver and colon cancer. Hepatology 57 2299-2313. (doi:10.1002/hep.26258)

Poomakkoth N, Issa A, Abdulrahman N, Abdelaziz SG \& Mraiche F 2016 p90 ribosomal S6 kinase: a potential therapeutic target in lung cancer. Journal of Translational Medicine 14 14. (doi:10.1186/s12967016-0768-1)

Provenzano PP \& Keely PJ 2009 The role of focal adhesion kinase in tumor initiation and progression. Cell Adhesion and Migration 3 347-350. (doi:10.4161/cam.3.4.9458)

Ray AK, Jones AC, Carnes DL, Cochran DL, Mellonig JT \& Oates TW Jr 2003 Platelet-derived growth factor-BB stimulated cell migration mediated through p38 signal transduction pathway in periodontal cells. Journal of Periodontology 74 1320-1328. (doi:10.1902/ jop.2003.74.9.1320)

Romeo Y, Zhang X \& Roux PP 2012 Regulation and function of the RSK family of protein kinases. Biochemical Journal 441 553-569. (doi:10.1042/BJ20110289)

Setia S, Nehru B \& Sanyal SN 2014 Upregulation of MAPK/Erk and PI3K/ Akt pathways in ulcerative colitis-associated colon cancer. Biomedicine and Pharmacotherapy 68 1023-1029. (doi:10.1016/j. biopha.2014.09.006)

Sever R \& Brugge JS 2015 Signal transduction in cancer. Cold Spring Harbor Perspectives in Medicine 5 pii: a006098. (doi:10.1101/ cshperspect.a006098)

Shen X, Qian L \& Falzon M 2004 PTH-related protein enhances MCF-7 breast cancer cell adhesion, migration, and invasion via an intracrine pathway. Experimental Cell Research 294 420-433. (doi:10.1016/j.yexcr.2003.11.028)

Shen X, Mula RV, Evers BM \& Falzon M 2007 Increased cell survival, migration, invasion, and Akt expression in PTHrP-overexpressing LoVo colon cancer cell lines. Regulatory Peptides 141 61-72. (doi:10.1016/j.regpep.2006.12.017)

Siegel RL, Miller KD \& Jemal A 2015 Cancer statistics, 2015. CA: Cancer Journal for Clinicians 65 5-29. (doi:10.3322/caac.21254)

Smith JA, Poteet-Smith CE, Xu Y, Errington TM, Hecht SM \& Lannigan DA 2005 Identification of the first specific inhibitor of p90 ribosomal S6 kinase (RSK) reveals an unexpected role for RSK in cancer cell proliferation. Cancer Research 65 1027-1034.

Snedecor G \& Cochran W 1989 Statistical Methods, 8th edition. Ames, IA, USA: Iowa State University Press.

Soki FN, Park SI \& McCauley LK 2012 The multifaceted actions of PTHrP in skeletal metastasis. Future Oncology 8 803-817. (doi:10.2217/ fon.12.76)
Sourbier C \& Massfelder T 2006 Parathyroid hormone-related protein in human renal cell carcinoma. Cancer Letters 240 170-182. (doi:10.1016/j.canlet.2005.08.020)

Sulzmaier FJ \& Ramos JW 2013 RSK isoforms in cancer cell invasion and metastasis. Cancer Research 73 6099-6105. (doi:10.1158/0008-5472. CAN-13-1087)

Walsh MF, Ampasala DR, Hatfield J, Vander Heide R, Suer S, Rishi AK \& Basson MD 2008 Transforming growth factor-beta stimulates intestinal epithelial focal adhesion kinase synthesis via smad- and p38-dependent mechanisms. American Journal of Pathology 173 385-399. (doi:10.2353/ajpath.2008.070729)

Wang Q, Li N, Wang X, Kim MM \& Evers M 2002 Augmentation of sodium butyrate-induced apoptosis by phosphatidylinositol 3'-kinase inhibition in the KM20 human colon cancer cell line. Clinical Cancer Research 8 1940-1947. (doi:10.4143/crt.2006.38.2.112)

Wu KL, Huang EY, Jhu EW, Huang YH, Su WH, Chuang PC \& Yang KD 2013 Overexpression of galectin-3 enhances migration of colon cancer cells related to activation of the K-Ras-Raf-ERK1/2 pathway. Journal of Gastroenterology 48 350-359. (doi:10.1007/s00535-0120663-3)

Wu CF, Liu S, Lee YC, Wang R, Sun S, Yin F, Bornmann WG, Yu-Lee LY, Gallick GE, Zhang W, et al. 2014 RSK promotes G2/M transition through activating phosphorylation of Cdc25A and Cdc25B. Oncogene 33 2385-2394. (doi:10.1038/onc.2013.182)

Wysolmerski JJ 2012 Parathyroid hormone-related protein: an update. Journal of Clinical Endocrinology and Metabolism 97 2947-2956. (doi:10.1210/jc.2012-2142)

Yang Y, Cheon S, Jung MK, Song SB, Kim D, Kim HJ, Park H, Bang SI \& Cho D 2015 Interleukin-18 enhances breast cancer cell migration via down-regulation of claudin-12 and induction of the p38 MAPK pathway. Biochemical and Biophysical Research Communications 459 379-386. (doi:10.1016/j.bbrc.2015.02.108)

Yu CF, Sanders MA \& Basson MD 2000 Human caco-2 motility redistributes FAK and paxillinand activates p38 MAPK in a matrixdependent manner. American Journal of Physiology: Gastrointestinal and Liver Physiology 278 G952-G966.

Yu J, Bian D, Mahanivong C, Cheng RK, Zhou W \& Huang S 2004 p38 mitogen-activated protein kinase regulation of endothelial cell migration depends onurokinase plasminogen activator expression. Journal of Biological Chemistry 279 50446-50454. (doi:10.1074/jbc. M409221200)

Zhang KS, Chen HQ, Chen YS, Qiu KF, Zheng XB, Li GC, Yang HD \& Wen CJ 2014 Bisphenol A stimulates human lung cancer cell migration via upregulation of matrix metalloproteinases by GPER/ EGFR/ERK1/2 signal pathway. Biomedicine and Pharmacotherapy 68 1037-1043. (doi:10.1016/j.biopha.2014.09.003)

Zhou Y, Yamada N, Tanaka T, Hori T, Yokoyama S, Hayakawa Y, Yano S, Fukuoka J, Koizumi K, Saiki I, et al. 2015 Crucial roles of RSK in cell motility by catalysing serine phosphorylation of EphA2. Nature Communications 9 7679. (doi:10.1038/ncomms8679)

Received in final form 2 April 2017

Accepted 6 April 2017

Accepted Preprint published online 6 April 2017 http://jme.endocrinology-journals.org

DOI: 10.1530/JME-16-0216
C 2017 Society for Endocrinology Printed in Great Britain
Published by Bioscientifica Ltd. 